\title{
Acute Metabolic Effects and Half-Lives of Intravenously Administered Insulinlike Growth Factors I and II in Normal and Hypophysectomized Rats
}

\author{
J. Zapf, C. Hauri, M. Waldvogel, and E. R. Froesch \\ Metabolic Unit, Department of Medicine, University Hospital, CH-8091 Zürich, Switzerland
}

\begin{abstract}
Insulinlike growth factors (IGF) act qualitatively like insulin on insulin target tissues in vitro. In the circulation in vivo they are bound to specific carrier proteins. In this form or when continuously infused into hypophysectomized (hypox) rats they do not exert acute insulinlike effects on glucose homeostasis.

This study definitively shows that intravenous bolus injections of pure IGF I or II act acutely on glucose homeostasis: they lower the blood sugar, enhance the disappearance of $U$ $\left[{ }^{14} \mathrm{C}\right] g$ lucose from serum and increase its incorporation into diaphragm glycogen in normal and hypox rats in the presence of antiinsulin serum. The same effects were obtained with recombinant human IGF I injected intravenously either with or without antiinsulin serum into normal rats.

Free fatty acid levels decreased transiently only in normal animals. Lipid synthesis from glucose in adipose tissue was not stimulated in hypox and barely stimulated in normal rats.

The half-life of injected IGF I or II in normal rats $(\sim 4 \mathrm{~h})$ is strikingly different from that in hypophysectomized rats $(20$ $30 \mathrm{~min}$ ) and appears to depend on the growth hormone-induced $150,000-200,000-m o l$ wt IGF carrier protein that is lacking in hypophysectomized rats.

$15 \mathrm{~min}$ after the bolus serum IGF I and II concentrations were similar to steady state levels during long-term infusion in hypox rats. Free IGF was barely detectable, however, in the infused animals, whereas $\mathbf{4 0 - 1 0 0 \%}$ was found free 15 min after the bolus. These observations for the first time confirm the hypothesis that only free IGF, but not the IGF carrier protein complex, is bioavailable to insulin target tissues.
\end{abstract}

\section{Introduction}

Insulinlike growth factors (IGF) $\mathrm{I}^{1,2}$ and II $(1,2)$ in their native form in serum circulate as large molecular weight complexes in

Preliminary aspects of this study have been presented at the 89th Ross Conference on Pediatric Research, Carefree, AZ, 8-11 November 1984, and at the 116th Ciba Foundation Symposium, London, 22-24 January 1985.

Please address reprint requests to Dr. Zapf.

Received for publication 21 August 1985 and in revised form $24 \mathrm{Feb}$ ruary 1986.

1. The amino acid sequences of somatomedin $\mathrm{C}(\mathrm{SmC})(3)$ and somatomedin A (SmA) (4) have been shown to be identical to that of IGF I (1). The three terms can, therefore, be considered synonyms for the same factor.

2. Abbreviations used in this paper: HSA, human serum albumin; hypox, hypothyroidectomized; IGF, insulinlike growth factor; NSILA-S, nonsuppressible insulinlike activity soluble in acid/ethanol.

J. Clin. Invest.

(c) The American Society for Clinical Investigation, Inc. 0021-9738/86/06/1768/08 $\$ 1.00$

Volume 77, June 1986, 1768-1775 which they are bound to specific serum carrier proteins (5-8). There is no evidence that complexed IGF, despite its high concentration in serum $(\sim 1 \mu \mathrm{g} / \mathrm{ml}[9])$, has any acute effects on glucose homeostasis. On the other hand, earlier experiments by Froesch et al. (10) and Oelz et al. (11) demonstrated that nonsuppressible insulinlike activity soluble in acid/ethanol (NSILAS), i.e., partially purified serum extracts containing IGF I and II ( $\sim 1 \%$ pure), lowered the blood sugar and stimulated glycogen and lipid synthesis in rats when injected intravenously together with antiinsulin serum. One of the criticisms raised at that time was that these effects might be artifacts due to impurities.

The aim of the present study was $(a)$ to reevaluate these earlier findings, this time with pure IGFs and in both normal and hypophysectomized (hypox) rats, $(b)$ to test whether pure IGF I and II differ in their acute in vivo potencies, $(c)$ to determine the half-lives of each the injected polypeptides, $(d)$ to compare the total and free serum levels attained after the bolus with those measured under steady state conditions in long-term infusion experiments $(12,13)$, and $(e)$ to compare some of the acute actions of pure IGF I isolated from human serum with those of IGF I obtained by recombinant DNA technology.

\section{Methods}

\section{Animals}

Normal male ZbZ Cara or ZUR:SIV and hypox male Tif RAI rats (kindly supplied by Dr. Meyer and Mr. Meier, Ciba Geigy, Basel, Switzerland) weighing between 120 and $140 \mathrm{~g}$ were used for all experiments. The animals had free access to food (Altromin, Lage, West Germany) and drinking water and were kept on a 12-h light/dark cycle. Hypophysectomy was carried out 3-4 wk after birth. Experiments were performed after additional 4 to $8 \mathrm{wk}$. Only those hypox animals were used whose body weight did not increase more than $2 \mathrm{~g} / \mathrm{wk}$.

Before the experiment, $2.2 \mathrm{ml}$ Valium $/ \mathrm{kg}$ body wt s.c. was injected. $1 \mathrm{ml}$ of saline/0.2\% human serum albumin (HSA) containing the following substances was injected into the tail vein 15-20 min later. Group 1: guinea pig antiinsulin serum ( 25 or $50 \mu \mathrm{l}$ in hypox or normal rats, respectively, neutralizing capacity $1.25 \mathrm{U} / \mathrm{ml}$; see below) and $1 \mu \mathrm{Ci}$ of $\mathrm{U}-\left[{ }^{14} \mathrm{C}\right]$ glucose with or without $40 \mathrm{mg}$ of unlabeled glucose (as indicated in the corresponding figures). These animals were used as controls. Group 2: $6 \mathrm{mU}$ of whale insulin (same amino acid sequence as pork insulin) without antiinsulin serum, but with $\mathrm{U}-\left[{ }^{14} \mathrm{C}\right]$ glucose and unlabeled glucose as in group 1; groups 3 and 4: $20 \mu \mathrm{g}$ of pure IGF I or II (this dose had been chosen because it corresponded to $6 \mathrm{mU}$ of insulin equivalents when standardized originally (14) in the fat pad assay of Froesch et al. [15]) and antiinsulin serum, $\mathrm{U}-\left[{ }^{14} \mathrm{C}\right]$ glucose and unlabeled glucose as in group 1. Animals were anesthetized with 1.8 (hypox rats) or $2.2 \mathrm{ml}$ (normal rats) phenobarbital/kg body wt i.p. before they were bled by aortic puncture at the time intervals given in the figures. Blood was collected on ice in glass tubes and centrifuged immediately after coagulation. The serum was pipetted off. Glucose was determined by a glucose analyzer (YSI, model 23A, Yellow Springs Instruments, Yellow Springs, OH). 25 $\mu l$ serum was counted for ${ }^{14} \mathrm{C}$-radioactivity in $10 \mathrm{ml}$ of Instagel (Packard Instruments, Inc., Downers Grove, IL) in a beta-counter (Packard). The rest of the serum was stored at $-20^{\circ} \mathrm{C}$ for determination of IGF I or II, and free fatty acids. 


\section{Materials}

Pure IGF I (batch I/3) and IGF II (batch 10 SE IV), and whale insulin were generous gifts from Dr. R. E. Humbel, Biochemisches Institut der Universität, Zurich. These IGF preparations came from the same stock from which Rinderknecht and Humbel had carried out amino acid sequence analyses $(1,2)$. When tested repeatedly for their biological potencies in the fat cell assay (14) against an insulin standard (whale insulin), $1 \mu \mathrm{g}$ of IGF I/ 3 corresponded to $\sim 100 \mu \mathrm{U}$, and $1 \mu \mathrm{g}$ of IGF II (10 SE IV) to $\sim 300 \mu \mathrm{U}$ of insulin equivalents. These values are $\sim 45 \%$ lower than those reported in 1978 (14). Possibly some loss in biological activity had occurred during storage over the years. However, the relative potency ratio between IGF I and II in the fat cell assay had remained the same as reported earlier (14).

Recombinant human IGF I (lot CGP 35126/III) was a generous gift of Dr. J. Nüesch (Ciba-Geigy, Basel). Its potencies in the IGF I radioimmunoassay (9) and in the fat cell assay (14) were indistinguishable from those of IGF I/3 from Dr. Humbel.

D-U $\left[{ }^{14} \mathrm{C}\right]$ glucose (specific radioactivity $>230 \mathrm{mCi} / \mathrm{mmol}$ ) was obtained from the Radiochemical Center, Amersham, U. K. Human serum albumin was supplied by the Swiss Red Cross, Bern, Switzerland. It was used after extensive dialysis against distilled water and subsequent sterile filtration.

Neutralizing capacity of the antiserum was determined radioimmunologically and biologically in the fat cell assay (14). In the radioimmunoassay binding of ${ }^{125} \mathrm{I}$-insulin (Medipro, Teufen, Switzerland) at increasing concentrations of unlabeled porcine insulin was measured at a constant antiserum dilution $(1: 150,000)$. From the binding-displacement curve maximal insulin binding was calculated by Scatchard plot analysis ( $1.25 \mathrm{mU}$ of insulin bound per $1 \mu \mathrm{l}$ of the antiserum). In the fat cell assay the effect of different antiserum dilutions on the stimulation of $U$ $\left[{ }^{14} \mathrm{C}\right]$ glucose incorporation by a constant insulin concentration $(100 \mu \mathrm{U} /$ $\mathrm{ml}$ ) was measured. Complete neutralization was achieved by $0.08 \mu \mathrm{l}$ of the antiserum with a half-maximal effect by $0.035 \mu l(90 \%$ neutralization by $0.055 \mu \mathrm{l})$.

$U-\left[{ }^{14} \mathrm{C}\right]$ glucose incorporation into diaphragm glycogen was determined as described earlier (16): diaphragms were boiled for $45 \mathrm{~min}$ in $2 \mathrm{ml}$ of $30 \% \mathrm{KOH}$ containing $5 \mathrm{mg}$ of $\mathrm{D}(+)$-glycogen (Fluka A. G., Buchs, Switzerland) as a carrier, thereby complete digestion of the tissue was achieved. After cooling on ice $5 \mathrm{ml}$ of absolute alcohol $\left(-20^{\circ} \mathrm{C}\right)$ was added. The samples were kept at $-20^{\circ} \mathrm{C}$ for $30 \mathrm{~min}$ and centrifuged for $10 \mathrm{~min}$ at $1,500 \mathrm{~g}$. The glycogen precipitate was washed twice with $5 \mathrm{ml}$ of absolute alcohol to which $100 \mu \mathrm{l}$ of $20 \% \mathrm{KOH}$ and $100 \mu \mathrm{l} 5 \% \mathrm{LiBr}$ had been added. After the final centrifugation the precipitate was dissolved in 2 $\mathrm{ml}$ of $0.1 \mathrm{~N} \mathrm{HCl}$. Of this solution $1.0 \mathrm{ml}$ was counted in $10 \mathrm{ml}$ of Instagel (Packard) in a beta-counter. Results were expressed as counts per minute per gram wet weight or as micromoles of glucose incorporated per gram wet weight. The latter index was calculated from the relative specific activity of the serum glucose as follows: relative specific ${ }^{14} \mathrm{C}$-radioactivity of serum glucose was first calculated for each rat by dividing the serum ${ }^{14} \mathrm{C}$-counts per milliliter by the corresponding blood sugar value expressed in micromoles per milliliter, and the decay curve was plotted as shown in Figs. $1 d$ and $3 d$. For each time point the area under this curve was calculated and the mean relative specific serum glucose radioactivity was obtained after dividing this number by the number of minutes at which aortic puncture had been performed. Under the assumption that most $(65-80 \%)$ of the ${ }^{14} \mathrm{C}$-radioactivity recovered in serum between 15 and $120 \mathrm{~min}$ corresponded to glucose (17) due to rapid recycling of nonglucose tissue metabolites back to glucose (18) glucose incorporation into glycogen was calculated by dividing the counts per minute incorporated per gram tissue by the corresponding mean relative specific serum glucose radioactivity. This rough approximation for calculating specific serum glucose radioactivity may result in $20-35 \%$ higher relative values (17) and may therefore underestimate glucose incorporation into tissues as depicted in Figs. 2 and 4 by $20-35 \%$.

\section{Incorporation of $U-\left[{ }^{14} \mathrm{C}\right]$ glucose into epididymal fat pad total lipids}

Epididymal fat pads were weighed and extracted for $3 \mathrm{~h}$ in $40 \mathrm{ml}$ of Folch's mixture (chloroform/methanol $2: 1$, vol/vol) in a horizontal shaker. The extract was filtered and evaporated to dryness under a stream of air. The remainder was taken up in $25 \mathrm{ml}$ of a $1: 1$ mixture ( $\mathrm{vol} / \mathrm{vol})$ of isooctane-acetic acid (shaking for $15 \mathrm{~s}$ ). $10 \mathrm{ml}$ of $0.05 \% \mathrm{H}_{2} \mathrm{SO}_{4}$ was added and the mixture was again shaken for $15 \mathrm{~s}$. It was then centrifuged for $20 \mathrm{~min}$ at $1,500 \mathrm{~g}$ and $4^{\circ} \mathrm{C}$ and the lower water phase (containing acetic acid and sulfuric acid) was sucked off with a capillary pipette connected with a vacuum pump. The upper isooctane phase containing the triglycerides was once more washed with $25 \mathrm{ml}$ of $0.05 \% \mathrm{H}_{2} \mathrm{SO}_{4}$, vigorously shaken and again centrifuged as above. The washing procedure was repeated a third time. $10 \mathrm{ml}$ of the isooctane phase was pipetted into a counting vial, evaporated to dryness under a stream of air, taken up in $10 \mathrm{ml}$ of Instagel and counted in a beta-counter (Packard).

\section{Radioimmunological determination of IGF I and II in the rat sera at different times after injection}

Total (carrier protein-bound plus free) IGF I and II. $0.5 \mathrm{ml}$ serum was gel filtered in $1 \mathrm{M}$ acetic acid on a Sephadex G-50 medium column (1.5 $\times 100 \mathrm{~cm}$, flow rate $27 \mathrm{ml} / \mathrm{h}$ ). The fractions eluting between 50 and $80 \%$ bed volume were collected, lyophilized, taken up in $8 \mathrm{ml}$ of $1 \mathrm{M}$ acetic acid, relyophilized, washed in $2 \mathrm{ml}$ of $0.1 \mathrm{M} \mathrm{NH}_{4} \mathrm{HCO}_{3}$ and lyophilized a third time. For IGF determination, the lyophilized material was dissolved in $1 \mathrm{ml}$ of phosphate-buffered saline (PBS)/0.2\% HSA, pH 7.4. $0.1 \mathrm{ml}$ of different dilutions from 1:2 to 1:50 was used for the determination of IGF I or II by radioimmunoassay as described earlier (9). Crossreactivity of rat IGF in the above $0.1 \mathrm{ml}$ samples was negligible for hypox rat serum, and at dilutions of these samples $>1: 10$ for normal rat serum. At lower dilutions, values were corrected for crossreactivity with endogenous rat IGF by using different dilutions of control serum, processed as described above, from $\mathrm{NaCl}$-injected normal or hypox rats. $\mathrm{Re}-$ covery by this procedure of pure IGF I and II preequilibrated with rat serum was between 72 and $80 \%$.

Free IGF I and II. $0.2-0.4 \mathrm{ml}$ of pooled serum from each group of rats was gel-filtered on a Sephadex G-50 medium column $(1.5 \times 60 \mathrm{~cm}$, flow rate $12 \mathrm{ml} / \mathrm{h}$ ) in $0.15 \mathrm{M} \mathrm{NH}_{4} \mathrm{HCO}_{3} / 0.02 \% \mathrm{HSA} / 0.02 \% \mathrm{NaN}_{3}(\mathrm{pH}$ 7.7). The elution range of free (nonprotein bound) IGF and its separation from the IGF-carrier complex was determined by chromatography of $0.5 \mathrm{ml}$ rat serum preequilibrated with ${ }^{125} \mathrm{I}-\mathrm{IGF}$ I or II $\left(10^{5} \mathrm{cpm}\right)$. The free tracers eluted between 49 and $75 \%$ of the bed volume. According to this separation pattern fractions eluting between 50 and $80 \%$ bed volume were pooled, lyophilized, taken up in $8 \mathrm{ml}$ of $0.1 \mathrm{M} \mathrm{NH}_{4} \mathrm{HCO}_{3}$ in $15-\mathrm{ml}$ glass vials and relyophilized. The dry material was dissolved in $0.5 \mathrm{ml}$ PBS (without HSA). The resulting HSA concentration in these samples was used for further dilutions of the samples (all samples were assayed at three to four different dilutions) as well as for the IGF I and II standard curves in the radioimmunoassay (RIA). Recovery by RIA of gel-filtered pure IGF I and II ( $20 \mathrm{ng}$ in $0.5 \mathrm{ml}$ phosphate-buffered saline, PBS $/ 0.2 \% \mathrm{HSA}$ ) in the $50-80 \%$ bed volume fraction was between 92 and $104 \%$. Values were corrected against the corresponding dilutions of control serum, processed as described above, from $\mathrm{NaCl}$-injected normal or hypox rats.

$50-80 \%$ bed volume fractions of control sera showed a small crossreaction in both RIAs. It corresponded to between 9 and $12 \mathrm{ng} / \mathrm{ml}$ serum for IGF I and II in hypox and for IGF II in normal rats and to 30-36 $\mathrm{ng} / \mathrm{ml}$ for IGF I in normal rats. More detailed analysis of this immunoreactive material in pools from 50 to 55,55 to 60,60 to 65 , and 65 to $80 \%$ bed volume showed that the major immunoreactivity appeared in the 50-55\% fraction and then fell sharply in the following fractions In contrast, the radioactive peak of gel-filtered ${ }^{125}$ I-IGF I and II eluted between 57 and $59 \%$ of the bed volume. The immunoreactive material in $50-80 \%$ bed volume fractions of control serum gel-filtered at neutral $\mathrm{pH}$ therefore is apparently not due to endogenous free IGF, but rather represents endogenous protein-bound IGF trailing into the $50-55 \%$ bed volume fraction. This will of course also be true for sera obtained after injection of exogenous IGF, so that the question arises whether and to what extent the values obtained in the $50-80 \%$ bed volume fractions actually represent free IGF. We cannot exclude that what we have measured as free IGF after the bolus injection also contains some "trailing" protein-bound IGF. The following points strongly suggest, however, that our free IGF values at least reflect a major nonprotein-bound IGF portion: 
(a) One would expect that the amounts of "trailing" protein-bound IGF are proportional to the total IGF levels. As shown in Fig. 5, this is not the case (except in normal rats between 30 and $120 \mathrm{~min}$ ). (b) Hypox serum after a 6-d IGF infusion, containing a similar total IGF concentration as hypox serum 15 min after the bolus, yields a "free" IGF value that is $4 \%$ of total as compared with between 40 and $75 \%$ in the acute experiments. Probably, the actual level of free IGF in the infusion experiments is even lower than $4 \%$ according to the above considerations. These findings also render it unlikely that dissociation of bound exogenous IGF during neutral gel filtration is of major importance.

Determination of serum free fatty acids. Free fatty acids were determined according to the method of Fahlholt (19) with slight modifications as described elsewhere (20).

Statistics. Student's $t$ test was used for statistical analysis.

\section{Results}

\section{Acute insulinlike effects}

Hypox rats. Fig. 1 shows the effects of IGF I and II injected intravenously together with antiinsulin serum and a trace amount of $\mathrm{U}-\left[{ }^{14} \mathrm{C}\right]$ glucose $(1 \mu \mathrm{Ci})$ on serum glucose $(a)$, serum free fatty acids $(b)$, serum ${ }^{14} \mathrm{C}$-radioactivity $(c)$, and on the specific ${ }^{14} \mathrm{C}$ activity of serum glucose $(d)$ in hypox rats. IGF I and II produced a clear-cut hypoglycemic effect with a nadir at $\sim 15 \mathrm{~min}$. At that time, the blood sugar was 46 and $41 \%$, respectively, below that of the control animals. Thereafter, the blood sugar values increased, but stayed significantly below those of the control

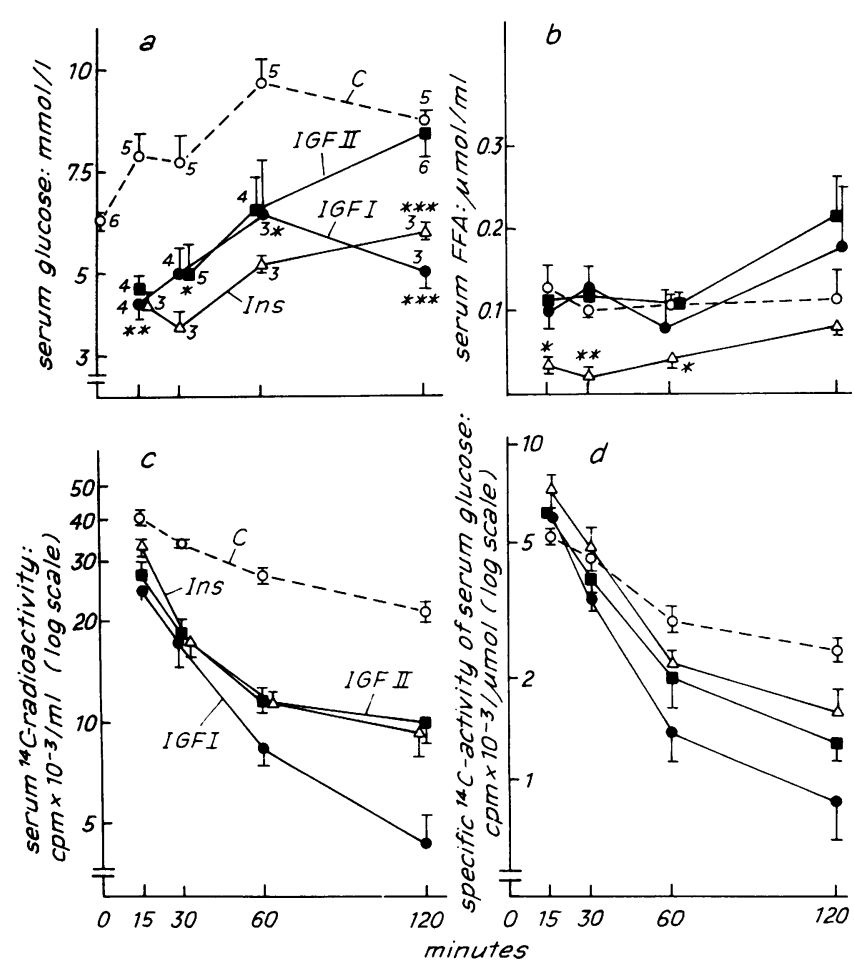

Figure 1. Serum glucose $(a)$, serum-free fatty acids $(b)$, serum- ${ }^{14} \mathrm{C}$-radioactivity $(c)$ and relative specific ${ }^{14} \mathrm{C}$-radioactivity of serum glucose (see Methods) (d) after intravenous injection of saline, IGF I or IGF II (20 $\mu \mathrm{g}$ together with anti-insulin serum and $1 \mu \mathrm{Ci}$ of $\mathrm{U}-\left[{ }^{14} \mathrm{C}\right]$ glucose) or insulin (6 $\mathrm{mU}$ without antiserum) into hypophysectomized rats. All values are the mean \pm SEM obtained in three to six rats from two to three different experiments. ०: controls (C); ๑: IGF I injected rats; $\bullet$ : IGF II injected rats; $\Delta$ : insulin-injected rats. ${ }^{*} P<0.05 ;{ }^{* *} P<0.01$; ***P$<0.001$ as compared with the control animals. group. The effects of IGF I and II were identical during the first $60 \mathrm{~min}$. The hypoglycemic effect of IGF II started to subside after $60 \mathrm{~min}$, whereas it persisted in the IGF I-treated animals. With $6 \mathrm{mU}$ of insulin (equivalent to $60 \mu \mathrm{g}$ of IGF I and to 20 $\mu \mathrm{g}$ of IGF II with respect to their in vitro potencies in the fat cell assay; see Methods) hypoglycemia was somewhat more pronounced at 30 and 60 min (statistically not significant).

Like insulin, IGF I and II enhanced the initial rate of the decrease of serum ${ }^{14} \mathrm{C}$ radioactivity as well as that of the relative specific ${ }^{14} \mathrm{C}$-activity of serum glucose (Fig. $1 c$ and $d$ ). In contrast to insulin, IGF I and II did not lower serum free fatty acid levels (Fig. $1 b$ ).

As shown in Fig. $2 a$, IGF I and II, like insulin, stimulated glycogen synthesis from $\mathrm{U}-\left[{ }^{14} \mathrm{C}\right]$ glucose in diaphragm significantly. In the control animals, newly synthesized glycogen at 15 min was apparently rapidly degraded by $30 \mathrm{~min}$. At that time glycogen synthesis was completely blocked and remained suppressed for the next $90 \mathrm{~min}$. The stimulatory effect of the three hormones was identical during the first $\mathbf{3 0} \mathrm{min}$. It disappeared after $60 \mathrm{~min}$ in the IGF II-injected animals, but lasted for another hour after injection of IGF I or insulin $(P<0.01$ at $120 \mathrm{~min}$ for IGF II as compared with IGF I).

Contrary to their pronounced effects on glycogen synthesis in diaphragm, IGF I and II had no effect at all on lipid synthesis from U- $\left[{ }^{14} \mathrm{C}\right]$ glucose in adipose tissue (Fig. $2 \mathrm{~b}$ ). $60 \mathrm{~min}$ after the injection of insulin a relatively small stimulatory effect on lipid synthesis was observed, which became more pronounced after $120 \mathrm{~min}$.

Neither the insulin nor the IGF I or II dose stimulated U$\left[{ }^{14} \mathrm{C}\right]$ glucose incorporation into liver glycogen (not shown).

Normal rats. The effects of IGF I and II on the above indices are shown for normal rats in Figs. 3 and 4: The rise of the blood sugar level observed in the control animals due to the administration of antiinsulin serum plus glucose was prevented by IGF

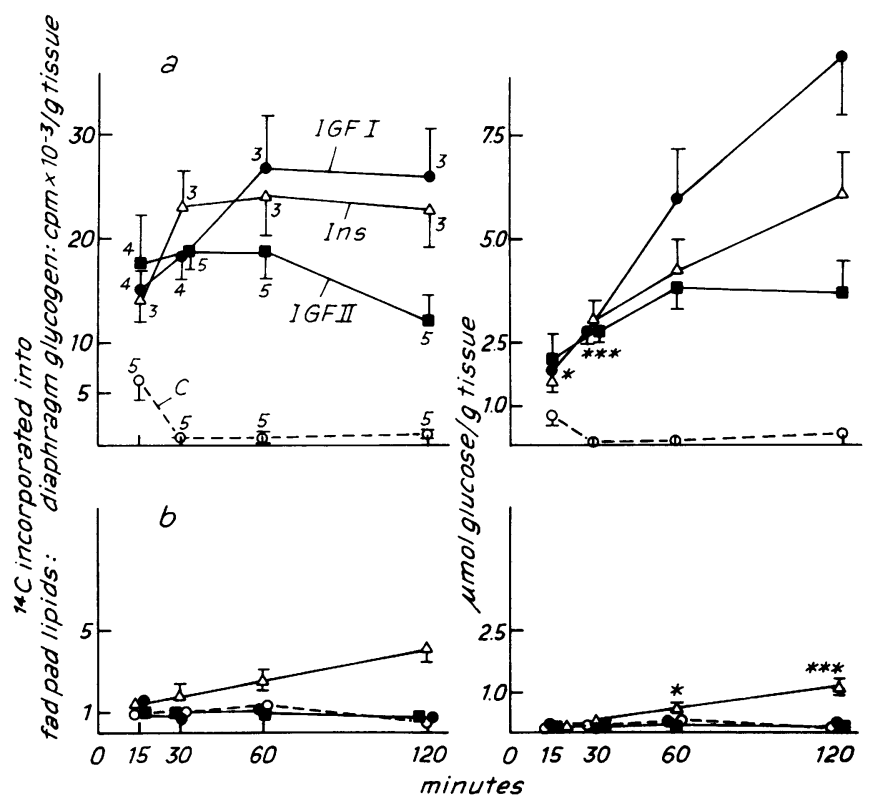

Figure 2. Effect of intravenously injected IGF I, IGF II (20 $\mu \mathrm{g}$ with antiinsulin serum and $1 \mu \mathrm{Ci}$ of $\mathrm{U}-\left[{ }^{14} \mathrm{C}\right]$ glucose) or insulin (6 mU without antiserum) on ${ }^{14} \mathrm{C}$-incorporation into diaphragm glycogen $(a)$ and into fat pad total lipids $(b)$ in hypophysectomized rats. $\dagger \dagger P<0.01$ as compared with IGF I. Symbols are the same as in Fig. 1. 

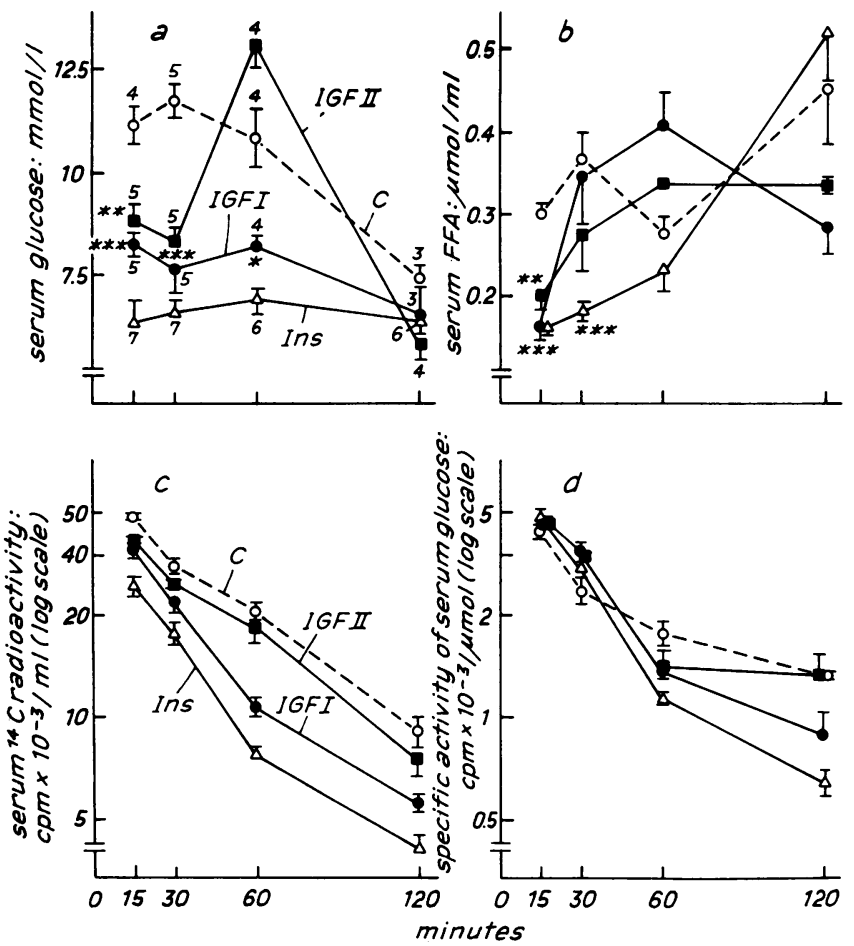

Figure 3. Serum glucose $(a)$, serum-free fatty acids $(b)$, serum ${ }^{14} \mathrm{C}$-radioactivity $(c)$ and relative specific ${ }^{14} \mathrm{C}$-radioactivity of serum glucose (see Methods) (d) after intravenous injection of saline, IGF I or IGF II (20 $\mu \mathrm{g}$ with antiinsulin serum, $1 \mu \mathrm{Ci}$ of $\mathrm{U}-\left[{ }^{14} \mathrm{C}\right] \mathrm{glucose}$ and $40 \mathrm{mg}$ of unlabeled glucose) or insulin ( $6 \mathrm{mU}$ without antiserum) into normal rats. Mean FFA levels \pm SEM at $15,30,60$, and 120 min after injection of saline $+\mathbf{4 0} \mathrm{mg}$ of glucose without antiinsulin serum were: $0.146 \pm 0.018,0.106 \pm 0.010,0.179 \pm 0.042$, and $0.230 \pm 0.016 \mu \mathrm{mol} / \mathrm{ml}$ $(n=3-5)$. Symbols are the same as in Fig. 1.

I and IGF II (Fig. $3 a$ ). IGF I tended to be somewhat more potent than IGF II, but the difference was statistically not significant. In contrast to IGF I, a consistent and conspicuous rise of the blood sugar level was observed between 30 and $60 \mathrm{~min}$ after the IGF II bolus. This "hyperglycemic effect" of IGF II coincided with a decreased disappearance rate of the injected $\mathrm{U}-\left[{ }^{14} \mathrm{C}\right]$ glucose from serum (Fig. $3 \mathrm{c}$ ). Blood sugar levels were lower after the insulin than after the IGF I bolus $(P<0.05$ at $15 \mathrm{~min} ; P<0.01$ at $60 \mathrm{~min}$ ).

The rise of the serum free fatty acids induced by the injection of antiinsulin serum was acutely inhibited by IGF I and II (Fig. $3 b$ ). However, this inhibitory effect was no longer seen at $\mathbf{3 0}$ min, whereas that of insulin lasted longer.

IGF I and II stimulated glycogen synthesis from U$\left[{ }^{14} \mathrm{C}\right]$ glucose in normal rat diaphragm less markedly than in the hypox animals (Figs. $4 a$ and $2 a$ ), whereas the stimulatory effect of insulin was comparable in both groups. Some breakdown of newly synthesized glycogen appears to occur at $30 \mathrm{~min}$ after the IGF I bolus although the difference between the 15- and 30-min values is not statistically significant. In the normal control animals, glycogen synthesis was completely suppressed for $30 \mathrm{~min}$. It increased slightly until $60 \mathrm{~min}$ and then started to rise sharply coinciding with the decrease of the blood sugar level (Fig. $3 a$ ) and with a marked increase of lipid synthesis (Fig. 4 b). Apparently, the insulin-neutralizing effect of the injected antiinsulin serum was overcome after $60 \mathrm{~min}$ by endogenous insulin.

As compared with insulin, the effects of IGF I and II on
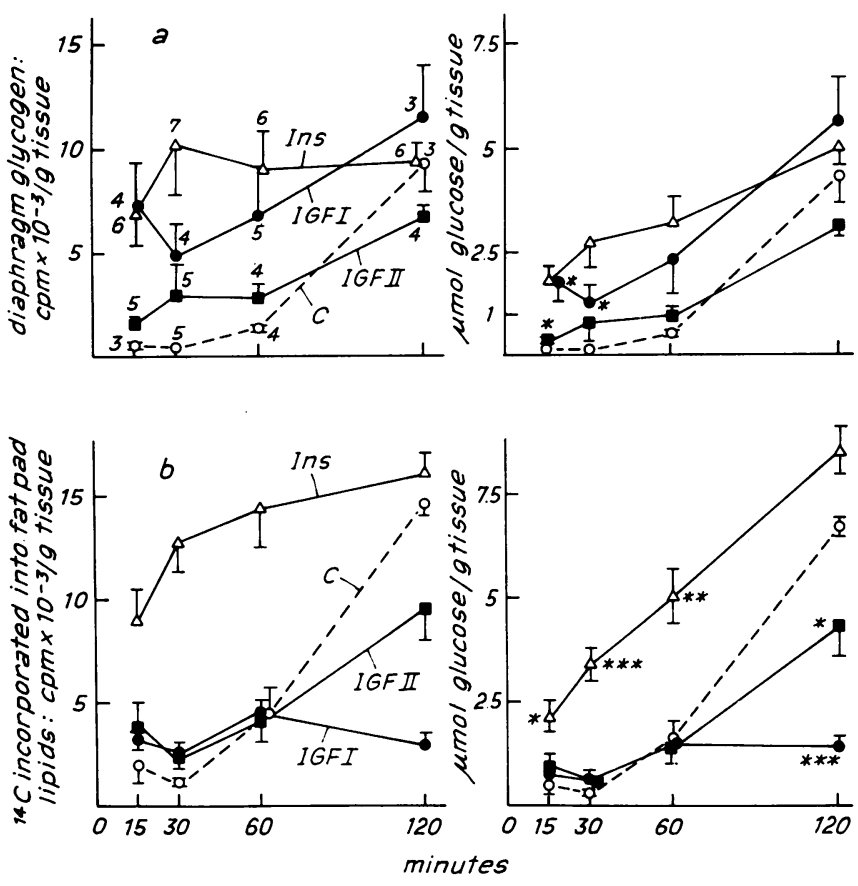

Figure 4. Effect of intravenously injected IGF I or IGF II (20 $\mu \mathrm{g}$ together with antiinsulin serum, $1 \mu \mathrm{Ci}$ of $\mathrm{U}-\left[{ }^{14} \mathrm{C}\right]$ glucose and $40 \mathrm{mg}$ of unlabeled glucose) or insulin (6 mU without antiserum) on ${ }^{14} \mathrm{C}$-incorporation into diaphragm glycogen $(a)$ and fat pad total lipids $(b)$ in normal rats. Symbols are the same as in Fig. 1.

lipid synthesis from U- $\left[{ }^{14} \mathrm{C}\right]$ glucose are minute and statistically not significant except for IGF I at $30 \mathrm{~min}(P<0.05)$ (Fig. $4 b$ ). In contrast to control animals, lipid synthesis did not increase 60 min after the injection of IGF I. This "suppressive effect" of IGF I was statistically highly significant $(P<0.001)$.

As in hypox rats, no stimulation of $\mathrm{U}-\left[{ }^{14} \mathrm{C}\right]$ glucose incorporation into liver glycogen was observed after the insulin or the IGF I or II bolus (not shown).

Acute effects of recombinant human IGF I (rh IGF I) on blood sugar and glycogen synthesis in diaphragm of normal rats. After completion of the study with IGFs isolated from human serum IGF I obtained by recombinant DNA technology became available. A few experiments were carried out with the biosynthetic polypeptide in normal rats. Two series of experiments were performed: in one the experimental design was identical to that described in materials and methods (i.e., administration of $20 \mu \mathrm{g}$ i.v. of rh IGF I together with antiinsulin serum, $1 \mu \mathrm{Ci}$ of $U-\left[{ }^{14} \mathrm{C}\right]$ glucose and $40 \mathrm{mg}$ of unlabeled glucose per rat) (Table I), in the other $40 \mu \mathrm{g}$ of $\mathrm{rh}$ IGF I i.v. was injected with $1 \mu \mathrm{Ci} \mathrm{U}$ $\left[{ }^{14} \mathrm{C}\right]$ glucose, but without unlabeled glucose and without antiinsulin serum (Table II). In both series a different strain of rats (ZUR:SIV) had to be used, because the ZbZ Cara strain was no longer available.

Table I shows that rh IGF I had the same effect on blood sugar, on the disappearance of ${ }^{14} \mathrm{C}$-radioactivity from serum and on glycogen synthesis in diaphragm as the "original" IGF I (Figs. 2 and 3): although the duration of the hyperglycemic effect of the antiinsulin serum in the ZUR:SIV control rats was shorter than in $\mathrm{ZbZ}$ Cara rats (15 instead of $30 \mathrm{~min}$ ), the blood sugar levels with $20 \mu \mathrm{g}$ of rh IGF I were significantly lower at 15 and 30 min than in the controls and identical to those observed in the $\mathrm{ZbZ}$ Cara rats treated with the "original" IGF I. 
Table I. Serum Glucose, Serum ${ }^{14} \mathrm{C}$-Radioactivity and Glucose Incorporation into Diaphragm

Glycogen after Intravenous Injection of $20 \mu \mathrm{g}$ of Recombinant Human IGF I Together with $50 \mu \mathrm{l}$ of Antiinsulin

Serum, $1 \mu C i$ of $U-\left[{ }^{14} \mathrm{C}\right]$ Glucose and $40 \mathrm{mg}$ of Unlabeled Glucose into Normal ZUR:SIV Rats

\begin{tabular}{|c|c|c|c|c|c|c|}
\hline & Controls & & & rh IGF I $(20 \mu \mathrm{g})$ & & \\
\hline Index (min) & 15 & 30 & 60 & 15 & 30 & 60 \\
\hline \multicolumn{7}{|l|}{ Serum glucose } \\
\hline (mmol/liter) & $10.37 \pm 0.50$ & $9.65 \pm 0.07$ & $8.32 \pm 0.25$ & $8.05 \pm 0.51^{*}$ & $7.62 \pm 0.15 \ddagger$ & $7.58 \pm 0.32$ \\
\hline \multicolumn{7}{|c|}{ Serum ${ }^{14} \mathrm{C}$-radioactivity } \\
\hline$(\mathrm{cpm} / \mathrm{ml})$ & $34,100 \pm 600$ & $28,500 \pm 370$ & $18,300 \pm 1,400$ & $25,500 \pm 810 \S$ & $20,100 \pm 950 \ddagger$ & $12,200+860^{*}$ \\
\hline \multicolumn{7}{|c|}{$\begin{array}{l}\text { Glucose incorporated } \\
\text { into diaphragm } \\
\text { glycogen: }\end{array}$} \\
\hline (cpm/g tissue) & $563 \pm 116$ & $149 \pm 6$ & $478 \pm 153$ & $7,009 \pm 1,826$ & $3,311 \pm 1,223$ & $3,568 \pm 968$ \\
\hline ( $\mu \mathrm{mol} / \mathrm{g}$ tissue $)$ & $0.14 \pm 0.029$ & $0.042 \pm 0.001$ & $0.155 \pm 0.05$ & $1.67 \pm 0.43^{*}$ & $0.92 \pm 0.34$ & $1.28 \pm 0.35^{*}$ \\
\hline
\end{tabular}

All values are the mean \pm SEM obtained in three to five rats for each time point ( 2 experiments). ${ }^{*} P<0.05 . \quad \ddagger P<0.001 . \quad \S P<0.01$, as compared with the corresponding controls.

The same was true for the decrease in ${ }^{14} \mathrm{C}$-serum radioactivity and for the stimulation of glycogen synthesis in diaphragm. Again, a transient breakdown of newly synthesized glycogen appears to occur at $30 \mathrm{~min}$ (statistically not significant). This phenomenon was not observed with insulin (Fig. 4 a) nor after 40 $\mu \mathrm{g}$ of rh IGF $\mathrm{I}$ in the absence of the glucose bolus and of the antiinsulin serum (Table II). In the latter series of experiments a transient, but clear-cut hypoglycemic effect of rh IGF I was seen at $15 \mathrm{~min}(P<0.05)$. Thereafter the blood sugar rose again to control levels. Glycogen synthesis was highly stimulated at all time points. At $15 \mathrm{~min}$ it was twice as high as with $20 \mu \mathrm{g}$ of rh IGF I in the presence of antiinsulin serum and with the glucose bolus (Table I).

\section{Half-lives of injected IGF, total and free IGF levels}

Fig. 5 shows the time course of the disappearance of intravenously injected IGF I and II from the serum of hypophysectomized and normal rats and the corresponding levels of free IGF I and II. In the hypox animals the disappearance rates of IGF I and II are almost linear over the first $60 \mathrm{~min}$, with an apparent half-life of $\sim 30$ and $\sim 20$ min, respectively. Whereas IGF II continues to disappear linearly and reaches a barely measurable level after $120 \mathrm{~min}$, the disappearance rate of IGF I becomes slower after $60 \mathrm{~min}$. The levels of free IGF I and II decrease more rapidly (half-lives $\sim 15$ and $\sim 7$ min, respectively). When the differences between total and free IGF levels corresponding to bound IGF I are calculated, the disappearance of bound IGF after equilibration with the carrier protein(s), i.e., after $\sim 20 \mathrm{~min}$ for IGF I and after $\sim 15 \mathrm{~min}$ for IGF II, parallels that of total IGF.

The initial disappearance rates of total IGF I and II were similar in normal and in hypox rats: IGF I and II concentrations at time zero extrapolated from the initial (15-30 $\mathrm{min}$ ) disappearance rates of total or free IGF I or II in hypox rats and of total and free IGF II in normal rats were between 350 and 400 $\mathrm{ng} / \mathrm{ml}$. Assuming a similar initial IGF I concentration for normal rats, its initial disappearance rate is the same as for IGF II $(\sim 15$ min). After 60 and $30 \mathrm{~min}$, respectively, the disappearance rates of IGF I and II decreased drastically. They were then nearly linear up to $240 \mathrm{~min}$ and more or less the same for both factors

Table II. Serum Glucose, Serum ${ }^{14} \mathrm{C}$-Radioactivity and Glucose Incorporation into Diaphragm Glycogen after Intravenous Injection of $40 \mu \mathrm{g}$ of Recombinant Human IGF I Together with $1 \mu \mathrm{Ci}$ of $U-\left[{ }^{14} \mathrm{C}\right] G l u c o s e$ but without Antiinsulin Serum and without Unlabeled Glucose into Normal ZUR:SIV Rats

\begin{tabular}{|c|c|c|c|c|c|c|}
\hline & Controls & & & rh IGF I $(40 \mu \mathrm{g})$ & & \\
\hline Index (min) & 15 & 30 & 60 & 15 & 30 & 60 \\
\hline \multicolumn{7}{|l|}{ Serum glucose } \\
\hline (mmol/liter) & $7.26 \pm 0.16$ & $6.54 \pm 0.15$ & $6.56 \pm 0.28$ & $4.93 \pm 0.62^{*}$ & $6.46 \pm 0.27$ & $5.99 \pm 0.25$ \\
\hline \multicolumn{7}{|c|}{ Serum ${ }^{14} \mathrm{C}$-radioactivity } \\
\hline$(\mathrm{cpm} / \mathrm{ml})$ & $28,600 \pm 1,400$ & $21,350 \pm 880$ & $14,800 \pm 620$ & $16,460 \pm 1,800 \ddagger$ & $13,150 \pm 2,630^{*}$ & $6,930 \pm 800 \ddagger$ \\
\hline \multicolumn{7}{|c|}{$\begin{array}{l}\text { Glucose incorporated } \\
\text { into diaphragm } \\
\text { glycogen: }\end{array}$} \\
\hline (cpm/g tissue) & $390 \pm 57$ & $766 \pm 173$ & $1,992 \pm 791$ & $14,000 \pm 1,880$ & $16,300 \pm 2,620$ & $21,500 \pm 2,630$ \\
\hline ( $\mu \mathrm{mol} / \mathrm{g}$ tissue $)$ & $0.084 \pm 0.01$ & $0.019 \pm 0.04$ & $0.59 \pm 0.23$ & $3.20 \pm 0.43 \ddagger$ & $4.61 \pm 0.74 \ddagger$ & $8.35 \pm 1.02 \ddagger$ \\
\hline
\end{tabular}

All values are the mean \pm SEM obtained in three rats for each time point (one experiment). ${ }^{*} P<0.05 . \quad \ddagger P<0.01$, as compared with the corresponding controls. 

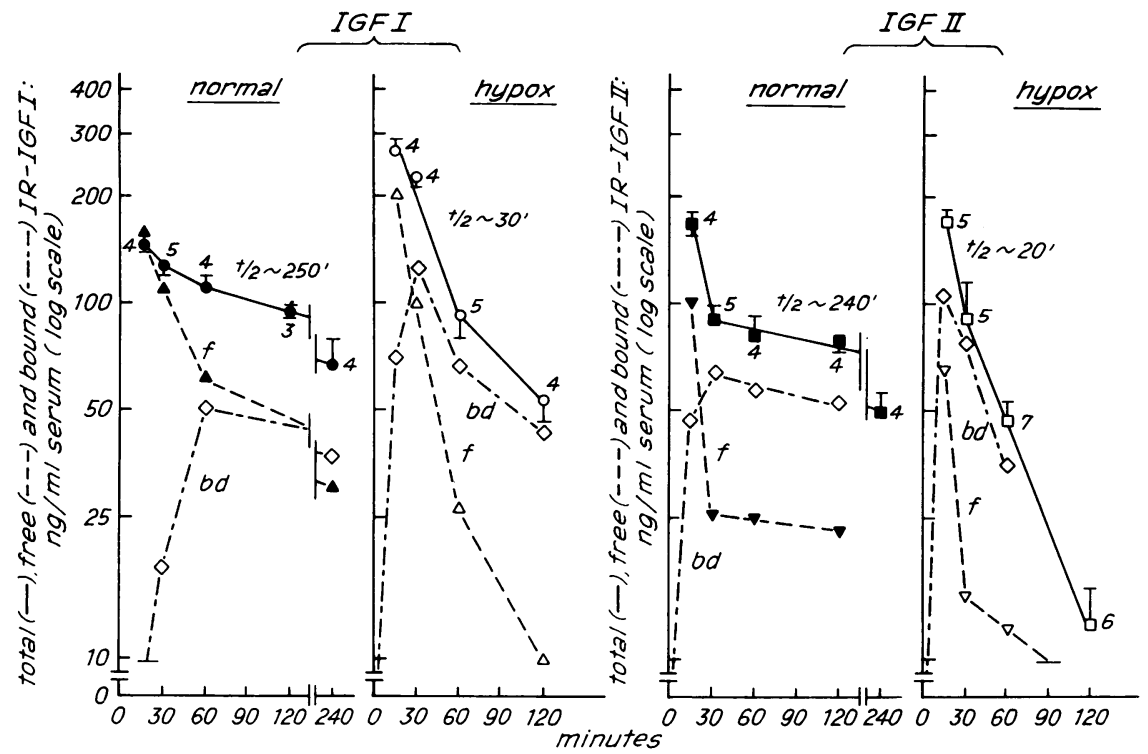

Figure 5. Time course of the disappearance of intravenously injected IGF I or IGF II $(20 \mu \mathrm{g} /$ rat) in normal and hypophysectomized rats. 0.5 ml serum obtained after different time intervals was gel-filtered on Sephadex G-50 medium in 1 $M$ acetic acid. The 50 to $80 \%$ bed volume fractions were pooled and lyophilized for determination of total IGF I or II (solid lines) in the IGF I or II RIA as described in Methods. 0.2$0.4 \mathrm{ml}$ of pooled serum obtained from three to six rats after different time intervals was gel-filtered on Sephadex G-50 medium in $0.15 \mathrm{M}$ $\mathrm{NH}_{4} \mathrm{HCO}_{3} / 0.02 \% \mathrm{HSA} / 0.02 \% . \mathrm{NaN}_{3}, \mathrm{pH} 7.7$. The $50-80 \%$ bed volume fractions were pooled and lyophilized for radioimmunological determination of nonprotein-bound IGF I or IGF II (broken lines) as described in Methods. Broken-dotted lines represent protein-bound IGF I or II. It has been calculated by subtracting nonprotein-bound from total IGF I or II. For total IGF the mean values \pm SEM determined in three to six experimental animals are given. $f$ $=$ free IGF; bd = protein-bound IGF

(calculated half-lives $\sim 4 \mathrm{~h}$ ). The change of the disappearance rates of total IGF is accompanied by a corresponding change of the disappearance rates of free IGF I and II. During the first 60 and $30 \mathrm{~min}$, respectively, free IGF I and II levels decrease much more rapidly than total IGF levels, but then the decay curves become parallel. Similarly, the disappearance of bound IGF I and II after apparent equilibration with the carrier proteins (i.e., after 45-60 min for IGF I and after 20-30 min for IGF II) parallels the disappearance rate of total and free IGF.

\section{Discussion}

The results of this study show (a) that in rats acute intravenous administration of pure IGF I or II isolated from human serum or of IGF I produced by recombinant DNA technology elicits acute effects on glucose homeostasis comparable to those of insulin, and $(b)$ that the effects of a single bolus of IGF I or II are quite different from the effects of sustained infusions of these growth factors.

The interference of endogenous insulin in the IGF experiments was temporarily eliminated by the simultaneous administration of antiinsulin serum so that the measured metabolic effects, at least during the first 30-60 min of the experiments, can be attributed to injected IGF and not to insulin. Of course, counterregulatory mechanisms-which, however, would rather mask IGF effects-cannot be completely excluded. In the control animals the antiinsulin serum caused an increase of the blood sugar which lasted $\sim 120$ min in hypox, but only $\sim 60 \mathrm{~min}$ in normal animals (except in the ZUR:SIV strain of rats where hyperglycemia lasted only for $30 \mathrm{~min}$ ). The duration of hyperglycemia may be considered as a reasonable index for the in vivo insulin neutralizing capacity of injected antiinsulin serum (21). The difference in the duration of hyperglycemia between normal and hypox rats may partly be due to the decreased production of endogenous insulin $(22,23)$ and its blunted response to glucose in the absence of growth hormone (24). In addition, normal rats received a glucose bolus in order to override counterregulatory mechanisms on glucose homeostasis that might mask the IGF effects. This bolus probably stimulated insulin release from the pancreas so that the insulin binding capacity of the antiserum was more rapidly saturated than in the hypox animals. Irrespective of these considerations, however, a 40- $\mu \mathrm{g}$ bolus of rh IGF I produced a clear-cut hypoglycemic effect and caused a highly significant stimulation of glycogen synthesis in diaphragm of normal rats also in the absence of antiinsulin serum and without an additional glucose bolus (Table II).

In both hypox and normal rats, the acute effects of the IGF I bolus lasted longer than those of the IGF II bolus. This would be in keeping with the observation that the serum concentrations of free IGF I remained longer elevated than those of IGF II (Fig. 5). The hyperglycemic effect of IGF II in normal rats remains unexplained. However, a qualitatively comparable although delayed increase (at $120 \mathrm{~min}$ ) of the blood sugar level was observed in the IGF II, but not in the IGF I injected hypox rats.

The finding that IGF I and II did not increase lipid synthesis from glucose in adipose tissue of hypox rats is consistent with earlier in vitro data on fat tissue and isolated fat cells from these animals: neither insulin nor IGFs caused a significant stimulation of lipid synthesis from glucose despite maximally activated glucose transport (25), a phenomenon that is not observed in muscle (16). In fat cells of hypox rats the key enzymes of the lipid synthesis pathway from glucose (pyruvate dehydrogenase, hexokinase) have been found to be drastically reduced (26). Thus, it is no longer glucose transport, but these enzymes that become rate limiting for glucose utilization in the adipocyte of the hypox rat.

The effects of IGF I and II on lipid synthesis in adipose tissue of normal rats appear minor or insignificant when compared with their effects on glycogen synthesis in diaphragm. Although the acute in vivo experiments with insulin are not directly comparable to those with IGF (because the latter were performed in the presence of antiinsulin serum) it appears that the in vivo potency at least of IGF II on adipose tissue is smaller than that determined in vitro: the IGF II bolus was equivalent to the insulin bolus when standardized with respect to the in vitro potency to stimulate lipid synthesis from glucose in rat adipocytes (see materials and methods). The preferential stimulation of muscle by IGF I and II is in keeping with earlier in vivo data obtained after intravenous injection of partially purified IGF preparations 
(NSILA-S) $(10,11)$, and with more recent in vitro data. The in vitro potency ratio between IGF I or II and insulin thus shifts from a value of $1 / 50$ to $1 / 100$ in adipose tissue (14) to $1 / 10$ to $1 / 20$ in striated muscle (27).

Surprisingly, no increase in lipid synthesis from glucose was observed between 1 and $2 \mathrm{~h}$ in the IGF I injected normal animals, while lipid synthesis was then considerably enhanced in the control animals. One possible explanation for this "suppressive effect" of IGF I may be the different glucose levels during the first hour of the experiment: the higher blood sugar levels in the control group have probably released more endogenous insulin than the suppressed glucose levels after the IGF I bolus. Therefore, the binding capacity of the antiserum may have been earlier saturated and overridden, and lipogenesis may then have been enhanced by endogenous insulin. It is likely that the suppressive effect of IGF I is caused by counterregulatory hormones to insulin.

The pronounced hypoglycemic effects of IGF I and II appear at first sight to contrast with the results obtained in long-term infusion experiments in hypox rats $(12,13)$. In the infused animals the blood sugar level did not decrease (13) although steady state IGF I and II concentrations during the infusion reached $\sim 300 \mathrm{ng} / \mathrm{ml}$ and were thus similar to or even higher than the total IGF I and II levels measured shortly after the bolus injection $(270 \pm 20$ and $170 \pm 15 \mathrm{ng} / \mathrm{ml}$, respectively, at $15 \mathrm{~min})$. By the same token, it may appear surprising that normal rats whose endogenous immunoreactive IGF I levels lie at around $200 \mathrm{ng} /$ $\mathrm{ml}$ (measured against a human IGF I standard; Zapf, unpublished observation) or normal humans with endogenous IGF (IGF I plus II) levels around $1 \mu \mathrm{g} / \mathrm{ml}(9)$, do not become hypoglycemic. This can now definitely be explained by the results of the present study: at a steady state IGF I level of $286 \mathrm{ng} / \mathrm{ml}$ that resulted from an infusion rate of $4.3 \mu \mathrm{g} / \mathrm{h}$ in the experiments of Schoenle et al. (12), free IGF I measured by the same methodology as described here was below $10 \mathrm{ng} / \mathrm{ml}$. We have recently repeated these experiments in hypox rats with biosynthetic human IGF I at infusion rates of 6 and $12 \mu \mathrm{g} / \mathrm{h}$. The steady state levels of IGF I measured after $6 \mathrm{~d}$ of infusion were 283 and 562 $\mathrm{ng} / \mathrm{ml}$. The body weight and the tibial epiphyses increased in proportion to the infused amounts of IGF, but no decrease of the blood sugar was observed (Guler et al., in preparation). "Free" IGF I levels were 10 and $20 \mathrm{ng} / \mathrm{ml}$, respectively (probably even lower, as explained in Methods). This means that $>96 \%$ of the infused IGF I circulated in the bound form and that neither the high steady state levels of bound IGF I nor the $10-20 \mathrm{ng} / \mathrm{ml}$ of "free" IGF I were able to exert measurable effects on glucose homeostasis. Similarly, endogenous IGF in native rat and human serum is complexed with specific carrier protein(s), and free IGF has so far not been detected. Meuli et al. have demonstrated in the perfused rat heart that complexed IGF in the circulation does not exert insulinlike effects (28) and, therefore, does not appear to be freely available to insulin target tissues. The above observations in the long-term IGF infusion experiments are in agreement with this notion. In contrast, after a bolus injection of $20 \mu \mathrm{g}$ per rat of IGF I or II, the binding capacity of the carrier protein(s) appears to be temporarily overridden. Relatively large amounts of free IGF are then present in the circulation (Fig. 5), can rapidly become distributed in the interstitial space and thus react with insulin and IGF receptors of insulin target tissues.

The different half-lives of injected IGFs in normal and hypox rats are striking and suggest that they depend on the growth hormone status of the animal. Comparable data have been re- ported by Cohen and Nissley (29) for the half-life of rat somatomedin activity. The results obtained with pure IGF I and II in our experiments are in line with this report, but in addition now show that IGF I and II do not behave completely identically with respect to their rates of disappearance and to their rates of equilibration with the carrier protein(s) (Fig. 5): Both in normal and in hypox rats, free IGF I remains longer elevated than free IGF II. Apparently, binding of IGF II to the specific carrier proteins in the serum (calculated as the difference between total and free IGF levels) is more rapid than binding of IGF I. Similarly, in vitro, ${ }^{125} \mathrm{I}$-IGF II tracer equilibrates faster with rat or human serum than ${ }^{125}$ I-IGF I (Zapf, unpublished observation). This is in agreement with the observation of Rechler et al. that the apparent affinity of rat serum somatomedin binding proteins is 10 times greater for IGF II than for IGF I (30).

The difference between the half-lives of IGF I or II in normal and hypox rats is likely to be due to the lack in hypox rat serum of the specific $150,000-200,000$-mol wt IGF carrier protein (these numbers do not represent true molecular weights, but the molecular weight ranges in which these proteins elute on Sephadex G-200 at neutral pH (for review see ref. 7 and 8]), which has been shown to be induced by growth hormone $(8,13,31,32)$ and to carry most of the endogenous rat somatomedin (33). Kaufmann et al. have injected ${ }^{125}$ I-NSILA-S intravenously into normal rats and measured the radioactivity associated with the $150,000-200,000$ and the $40,000-50,000$-mol wt IGF carrier proteins at different time intervals by neutral gel-filtration of serum on Sephadex G-200. These authors observed that the radioactive 150,000-200,000-mol wt peak increased during the $1 \mathrm{st} \mathrm{h}$ and then declined with a half-life of $\sim 3 \mathrm{~h}$, whereas the half-life of the radioactive 40,000-50,000-mol wt peak was $<20$ min (32). We have recently performed the same experiments with ${ }^{125}$ I-IGF I and II in hypox rats and found that the half-lives of the two tracers associated with the 40,000-50,000-mol wt carrier protein, the only IGF carrier protein present in hypox serum, was between 15 and $20 \mathrm{~min}$.

The finding that most of the endogenous rat somatomedin is associated with the $150,000-200,000-\mathrm{mol}$ wt carrier protein (33) would fit the observation that the half-life of injected IGF is prolonged in the presence of the latter protein. Both observations suggest that at least in vivo the apparent affinity of IGFs towards this protein is greater than that toward the $40,000-$ 50,000-mol wt carrier protein.

Altogether, the results of this study complement those obtained on long-term in vivo actions of IGFs $(12,13)$. They definitely show that both IGF I and II, besides their growth-promoting effects in hypox rats, can acutely influence glucose homeostasis in normal and hypox rats. The acute effects, however, become only manifest when the concentrations of free IGF reach levels that are high enough to stimulate insulin target organs. This condition is apparently not fulfilled under physiological conditions in vivo or during continuous infusion of a limited amount of IGF that does not oversaturate the binding capacity of the specific IGF carrier proteins. It may be expected that higher infusion rates than those previously used will not only promote growth, but also significantly affect glucose homeostasis.

\section{Acknowledgments}

We thank Ms. R. Meister and Ms. M. Salman for typing the manuscript.

This work was supported by grant 3.167-0.81 and 3.051-0.84 of the Swiss National Science Foundation. 


\section{References}

1. Rinderknecht, E., and R. E. Humbel. 1978. The amino acid sequence of human insulin-like growth factor I and its structural homology with proinsulin. J. Biol. Chem. 253:2769-2776.

2. Rinderknecht, E., and R. E. Humbel. 1978. Primary structure of human insulin-like growth factor II. Fed. Eur. Biochem. Soc. 89:283286.

3. Klapper, D. C., M. E. Svoboda, and J. J. Van Wyk. 1983. Sequence analysis of somatomedin-C: confirmation of identity with insulin-like growth factor I. Endocrinology. 112:2215-2217.

4. Enberg, G., M. Carlquist, H. Jörnvall, and K. Hall. 1984. The characterization of somatomedin $\mathrm{A}$, isolated by microcomputer-controlled chromatography, reveals an apparent identity to insulin-like growth factor I. Eur. J. Biochem. 143:117-124.

5. Zapf, J., E. R. Froesch, and R. E. Humbel. 1981. The insulin-like growth factors (IGF) of human serum: chemical and biological characterization and aspects of their possible physiological role. Curr. Top. Cell. Regul. 19:257-309.

6. Hintz, R. L. 1984. Plasma forms of somatomedins and the binding protein phenomenon. In Clinics in Endocrinology and Metabolism Vol 13. Tissue growth factors. W. H. Daughaday, editor. W. B. Saunders Co., Philadelphia. 31-42.

7. Nissley, S. P., and M. M. Rechler. 1984. Insulin-like growth factors, somatomedins and multiplication stimulating activity. Biosynthesis and receptors. In Hormonal Proteins and Peptides. C. H. Li, editor. Academic Press, Orlando, FL. 127-203.

8. D'Ercole, A. J., and J. R. Wilkins. 1984. Affinity labeled somatomedin-C-binding proteins in rat sera. Endocrinology. 114:1141-1144.

9. Zapf, J., H. Walter, and E. R. Froesch. 1981. Radioimmunological determination of insulin-like growth factors I and II in normal subjects and in patients with growth disorders and extrapancreatic tumor hypoglycemia. J. Clin. Invest. 68:1321-1330.

10. Froesch, E. R., W. A. Müller, H. Bürgi, M. Waldvogel, and A. Labhart. 1966. Nonsuppressible insulin-like activity of human serum. II. Biological properties of plasma extracts with nonsuppressible insulinlike activity. Biochim. Biophys. Acta. 121:360-374.

11. Oelz, O., A. Jakob, and E. R. Froesch. 1970. Nonsuppressible insulin-like activity (NSILA) of human serum. V. Hypoglycemia and preferential metabolic stimulation of muscle by NSILA-S. Eur. J. Clin. Invest. 1:48-53.

12. Schoenle, E., J. Zapf, R. E. Humbel, and E. R. Froesch. 1982. Insulin-like growth factor I stimulates growth in hypophysectomized rats. Nature (Lond.) 296:252-253.

13. Schoenle, E., J. Zapf, Ch. Hauri, Th. Steiner, and E. R. Froesch. 1985. Comparison of in vivo effects of insulin-like growth factors I and II and of growth hormone in hypophysectomized rats. Acta Endocrinol. 108:167-174.

14. Zapf, J., E. Schoenle, and E. R. Froesch. 1978. Insulin-like growth factors I and II: Some biological actions and receptor binding characteristics of two purified constituents of nonsuppressible insulin-like activity of human serum. Eur. J. Biochem. 87:285-296.

15. Froesch, E. R., H. Bürgi, E. B. Ramseier, P. Bally, and A. Labhart. 1963. Antibody-suppressible and nonsuppressible insulin-like activities in human serum and their physiologic significance. An insulin assay with adipose tissue of increased precision and specificity. J. Clin. Invest. 42:1816-1834.

16. Zapf, J., M. Waldvogel, E. Schoenle, and E. R. Froesch. 1981. Effect of insulin on glucose transport and metabolism in adipose tissue and skeletal muscle of hypophysectomized rats. Fed. Eur. Biochem. Soc. 135:199-202.

17. Björntorp, P., M. Krotkiewski, B. Larsson, and Z. Somlo-Szücs. 1970. Effects of feeding states on lipid radioactivity in liver, muscle and adipose tissue after injection of labelled glucose in the rat. Acta Physiol. Scand. 80:29-38.

18. Baker, N., R. A. Shipley, R. E. Clark, and G. E. Incefy. 1959. ${ }^{14} \mathrm{C}$-studies in carbohydrate metabolism. III. Glucose pool size and rate of turnover in the normal rat. Am. J. Physiol. 196:245-252.

19. Fahlholt, K., B. Lund, and W. Fahlholt. 1973. An easy colorimetric micromethod for routine determination of free fatty acids in plasma. Clin. Chim. Acta. 46:105-111.

20. Zapf, J., E. Schoenle, M. Waldvogel, I. Sand, and E. R. Froesch. 1981. Effect of trypsin treatment of rat adipocytes on biological effects and binding of insulin and insulin-like growth factors. Eur. J. Biochem. 113:605-609.

21. Robinson, B. H. B., and P. H. Wright. 1961. Guinea pig antiinsulin serum. J. Physiol. (Lond.) 155:302-

22. van Lan, V., N. Yamaguchi, M. J. Garcia, E. R. Ramey, and J. C. Penhos. 1974. Effect of hypophysectomy and adrenalectomy on glucagon and insulin concentration. Endocrinology. 94:671-

23. Heinze, E., W. Kleinert, and K. H. Voigt. 1981. Insulin release in rats 1 and 5 days after hypophysectomy. Horm. Res. 14:243-

24. Merimee, T. J., D. L. Rimoin, D. Rabinowitz, and L. L. CavalliSforza. 1968. Metabolic studies in the African pygmy. Trans. Assoc. Am. Phys. 1(xxxi):221-230.

25. Schoenle, E., J. Zapf, and E. R. Froesch. 1979. Receptor binding and effects of insulin and NSILA-S on glucose transport and metabolism in adipocytes from hypophysectomized rats. Diabetologia. 16:41-46.

26. Bay, U., and E. R. Froesch. 1983. Glucose phosphorylation: limiting step in glucose metabolism of adipocytes of hypophysectomized rats in the absence and presence of insulin. Diabetologia. 25:139 (Abstr. 24).

27. Poggi, C., Y. le Marchand-Brustel, J. Zapf, E. R. Froesch, and P. Freychet. 1979. Effects of binding of insulin-like growth factor I in the isolated soleus muscle of lean and obese mice: comparison with insulin. Endocrinology. 105:723-730.

28. Meuli, C., J. Zapf, and E. R. Froesch. 1978. NSILA-carrier protein abolishes the action of nonsuppressible insulin-like activity (NSILA-S) on perfused rat heart. Diabetologia. 14:253-259.

29. Cohen, K. L., and S. P. Nissley. 1976. The serum half-life of somatomedin activity: evidence for growth hormone dependence. Acta Endocrinol. 83:243-258.

30. Rechler, M. M., J. Zapf, S. P. Nissley, E. R. Froesch, A. C. Moses, J. M. Podskalny, E. E. Schilling, and R. E. Humbel. 1980. Interactions of insulin-like growth factors I and II and multiplication-stimulating activity with receptors and serum carrier proteins. Endocrinology. 107: 1451-1459.

31. Moses, A. C., S. P. Nissley, K. L. Cohen, and M. M. Rechler. 1976. Specific binding of a somatomedin-like polypeptide in rat serum depends on growth hormone. Nature (Lond.). 263:137-140.

32. Kaufmann, U., J. Zapf, and E. R. Froesch. 1978. Growth hormone dependence of nonsuppressible insulin-like activity (NSILA) and of NSILA-carrier protein in rats. Acta Endocrinol. 87:716-727.

33. Moses, A. C., S. P. Nissley, J. Passamani, R. M. White, and M. M. Rechler. 1979. Further characterization of growth hormone-dependent somatomedin-binding proteins in rat serum and demonstration of somatomedin-binding proteins produced by rat liver cells in culture. Endocrinology. 104:536-546. 